\title{
Proximate and mineral composition of plantain (Musa Paradisiaca) wastes flour; a potential nutrients source in the formulation of animal feeds
}

\author{
O.T. Okareh ${ }^{1}$, A.T. Adeolu ${ }^{*^{1}}$, O.T. Adepoju ${ }^{2}$ \\ ${ }^{1}$ Department of Environmental Health Sciences, Faculty of Public Health, College of Medicine, University of Ibadan, \\ Ibadan, Oyo State, Nigeria. \\ ${ }^{2}$ Department of Human Nutrition, Faculty of Public Health, College of Medicine, \\ University of Ibadan, Ibadan, Oyo State, Nigeria \\ Corresponding author Email: deetee4all@yahoo.com
}

ABSTRACT

\begin{abstract}
Plantain fruit constitute an important source of energy as a staple diet in the tropics. The peel of the fruit is discarded as waste after the edible portion is eaten; thereby constituting a menace to the environment, especially where its consumption is common, while the bracts, fruit stalk and leaf are left on the farm as wastes. These waste materials have been considered for use as organic fertilizer in some countries. This study was carried out to determine the proximate and mineral composition of plantain (Musa paradisiaca) wastes flour as possible sources of nutrients in formulating animal feeds. The proximate and mineral composition of plantain wastes (bract, ripe peel, fruit stalk and leaf) were determined using standard methods of analyses of AOAC and atomic absorption spectrophotometric method. The wastes contained between 9.39 and $9.53 \mathrm{~g}$ moisture, 1.87 and $19.37 \mathrm{~g}$ crude protein, 0.73 and $1.83 \mathrm{~g}$ crude fat, 8.10 and $15.50 \mathrm{~g}$ crude fibre, and 54.00 and $68.00 \mathrm{~g}$ carbohydrate $/ 100 \mathrm{gsample}$. Plantain bract is very rich in iron $(10.50-14.00 \mathrm{mg})$, calcium $(120.00-150.00 \mathrm{mg})$ and phosphorus $(110.00-180.00 \mathrm{mg}) / 100 \mathrm{~g}$ sample. The plantain wastes can be sources of nutrients in animal feed preparation, as they are high in protein, fibre and essential mineral content. This will result in dual benefits of its use as animal feeds and proper plantain wastes management (waste reduction) strategy, as the wastes would have constitute nuisance to the environment.
\end{abstract}

Keywords: Proximate and mineral composition, animal feeds, plantain waste management.

\section{INTRODUCTION}

Plantain is one of the most important crops of the tropical plants. It belongs to the family Musaceae and the genus Musa. Musa paradisiaca, also known as plantain (English), 'Ogede agbagba' (Yoruba), 'Ayaba' (Hausa) and 'Ogadejioke' (Igbo), is a tropical plant that is native to India. The plant consists of long, overlapping leafstalks and bears a stem which is 1.22 to $6.10 \mathrm{~m}$ high (Oladiji et al., 2010), with a life span of about 15 years (Philips, 1982). The fruits grow in clusters, each separate plantain of the cluster being about 1 inch in diameter and somewhat longer than a banana fruit. Plantain fruit requires about two and a half to four months after shooting before the fruit becomes ready for harvesting or a total of about eight to twelve months after planting (Swennen, 1990a).
Plantain contains a high fibre content, and thus is capable of lowering cholesterol and helps to relieve constipation and hence prevention of colon cancer. Besides this, its high potassium content is found to be useful in the prevention of raising blood pressure and muscle cramp ( $\mathrm{Ng}$ and Fong, 2000). Various parts of the plant such as the leaves, root, fruit stalk, bract and fruit have been used for medicinal and domestic purposes. The fruit is consumed as food, the leaf juice is used in the treatment of fresh wounds, cuts and insect bites while the leaves act as an arbortifacient. Its sap is used as a remedy for diarrhoea, dysentery, hysteria and epilepsy. A cold infusion of the root is used to treat venereal diseases and anaemia. In addition, the fruit has been reportedly used as antiscorbutic, aphrodisiac and diuretic (Gill, 
1992). Adeniji, et al., (2006) reported $100 \mathrm{~g}$ edible portion of plantain to contain $67.30 \mathrm{~g}$ moisture, $0.4 \mathrm{~g}$ crude fat, $31.15 \mathrm{~g}$ carbohydrate, $0.95 \mathrm{mg}$ potassium, $35.1 \mathrm{mg}$ sodium, $71.5 \mathrm{mg}$ calcium, $28 \mathrm{mg}$ phosphorus, $2.4 \mathrm{mg}$ iron, and yielded $116 \mathrm{kcal}$ of energy.

Plantain peels are by-products of the plantain processing industry, which are normally dumped in landfills, rivers or unregulated grounds (Osma et al., 2007). The peel of the fruit is discarded as waste after the inner fleshy portion has been eaten, thereby constituting a menace to the environment, especially where its consumption is common. Omole et al (2008) reported that the peel has the potentials of replacing corn starch in the diet of snail, while the bracts, fruit stalk and leaf at times are left in the farm as wastes. Leaves, pseudostems, fruit stalks and peels, after chopping, fermentation, and drying, yield a meal somewhat more nutritious than alfalfa press-cake. These waste materials have been considered for use as organic fertilizer in Somalia. In Malaya, pigs fed with pseudostems are less prone to liver and kidney parasites than those on other diets.

In view of the need for waste management and upsurge in the prizes of livestock feeds coupled with their increasing demand, this study was conducted to determine the proximate and mineral composition of Musa paradisiaca wastes (bracts, fruit stalk, leaf and peel) flour for possible utilization as livestock feeds.

\section{MATERIALS AND METHODS}

\section{Plantain Wastes Sample Preparation}

Ripe plantain fruit was purchased at Oje market in Ibadan, Oyo State, Nigeria while plantain bracts, fruit stalk, and leaves were collected from plantain plantation in Ilesa, Osun State, Nigeria. The peel, bract, fruit stalk and leaves were removed, washed with distilled water, sun dried for 168 hours and then oven dried at $105^{\circ} \mathrm{C}$ to constant weight. The samples were grinded, passed through a $0.1 \mathrm{~mm}$ mesh size and, stored in polythene container till when needed for analysis.

\section{Chemicals and Reagents}

All the chemicals and reagents used in this study were of analytical grade and were products of British drug House Laboratory, England.

\section{Proximate Composition}

The proximate nutrient composition of the samples was determined using the standard methods of analysis of Association of Official Analytical Chemists (AOAC, 1995).
Moisture content of the samples was determined by air oven (Gallenkamp) method at $105^{\circ} \mathrm{C}$. The crude protein of the samples was determined using micro-Kjeldahl method. Crude lipid was determined by Soxhlet extraction method using petroleum ether as extracting solvent. The ash content was determined using a muffle furnace set at $550^{\circ} \mathrm{C}$ for 4 hours until constant weight of ash is obtained. Crude fibre was determined using the method of Saura-Calixto et al. (1983). The carbohydrate content was obtained by difference.

\section{Mineral analysis}

Potassium and sodium were determined by digesting the ash of the samples with perchloric acid and nitric acid, and then taking the readings on Jenway digital flame photometer/spectronic 20 (Bonire et al., 1990).

Phosphorus was determined by vanado-molybdate colorimetric method (Ologhobo and Fetuga, 1983). Calcium, magnesium and iron were determined spectrophotometrically by using Buck 200 atomic absorption spectrophotometer (Buck Scientific, Norwalk) (Essien et al., 1992) and their absorption compared with absorption of standards of these minerals.

\section{Statistical analysis}

All determinations were carried out in triplicates. Descriptive statistics, analysis of variance (ANOVA) and Duncan Multiple Range Test were used to interprete the results obtained, and the level of significance was set at $p$ $\leq 0.05$.

\section{RESULTS}

The result of proximate nutrient composition of plantain wastes is as shown in Table 1 . The residual moisture content of plantain wastes was very low (less than $10 \mathrm{~g} / 100 \mathrm{~g}$ sample). The moisture content of bracts, ripe peel and fruit stalk was not significantly different from each other $(p>0.05)$, while their value was significantly lower than that of the leaf $(p<0.05)$. The protein content of the waste products was significantly different from each other with leaf protein being the highest, followed by bract, the fruit stalk having the lowest value. The crude lipid content of bract and leaf was not significantly different but was significantly different from that of ripe peel and fruit stalk $(p<0.05)$. The ash value of all samples was significantly different from each other, fruit stalk having the highest value followed by ripe peel, with the leaf having the lowest. The crude fibre content of the waste products was significantly different from one another, fruit stalk having the highest value followed by ripe peel, bract and leaf $(p<0.05)$. The carbohydrate 
Table 1. Proximate composition (Dry Matter, DM) of plantain wastes flour ( $g / 100 \mathrm{~g}$ )

\begin{tabular}{lccccc}
\hline Sample & Bract & Ripe peel & Fruit stalk & Leaf & Mean \\
\hline Moisture & $9.5^{\mathrm{b}} \pm 0.1$ & $9.5^{\mathrm{b}} \pm 0.2$ & $9.5^{\mathrm{b}} \pm 0.1$ & $9.4^{\mathrm{a}} \pm 0.3$ & $9.4 \pm 0.3$ \\
Protein & $11.5^{\mathrm{c}} \pm 0.2$ & $2.3^{\mathrm{b}} \pm 0.6$ & $1.9^{\mathrm{a}} \pm 06$ & $19.4^{\mathrm{d}} \pm 0.3$ & $8.7 \pm 0.5$ \\
Crude lipid & $1.8^{\mathrm{c}} \pm 0.1$ & $0.9^{\mathrm{b}} \pm 0.1$ & $0.7^{\mathrm{a}} \pm 0.6$ & $1.8^{\mathrm{c}} \pm 0.6$ & $1.3 \pm 0.5$ \\
Ash & $7.8^{\mathrm{b}} \pm 0.6$ & $8.9^{\mathrm{c}} \pm 0.6$ & $9.1^{\mathrm{a}} \pm 0.6$ & $7.2^{\mathrm{a}} \pm 0.1$ & $8.2 \pm 0.8$ \\
Crude Fibre & $8.5^{\mathrm{b}} \pm 0.1$ & $10.4^{\mathrm{c}} \pm 0.6$ & $15.5^{\mathrm{a}} \pm 0.1$ & $8.1^{\mathrm{a}} \pm 0.2$ & $10.6 \pm 3.1$ \\
Carbohydrates & $60.9^{\mathrm{b}} \pm 0.5$ & $68.0^{\mathrm{a}} \pm 0.3$ & $63.3^{\mathrm{c}} \pm 0.2$ & $54.6^{\mathrm{a}} \pm 0.3$ & $61.7 \pm 5.1$ \\
\hline
\end{tabular}

All data were mean \pm standard deviation of triplicate determinations

Means within the same column with the same subscripts were not significantly different (Duncan's test)

Table 2. Mineral composition (Dry Matter, DM) of plantain wastes flour (mg/100g)

\begin{tabular}{lcccccc}
\hline Sample & $\mathbf{N a}$ & $\mathbf{K}$ & $\mathbf{C a}$ & $\mathbf{M g}$ & $\mathbf{P}$ & $\mathbf{F e}$ \\
\hline Bract & $280.0^{\mathrm{b}} \pm 0.0$ & $40.0 \pm 0.0$ & $135.0 \pm 0.0$ & $18.0^{\mathrm{d}} \pm 0.0$ & $151.7^{\mathrm{c}} \pm 2.9$ & $14.0^{\mathrm{c}} \pm 0.0$ \\
Ripe peel & $315.0^{\mathrm{c}} \pm 12.0$ & $35.0 \pm 0.0$ & $120.0 \pm 0.0$ & $14.5^{\mathrm{b}} \pm 0.0$ & $145.0^{\mathrm{b}} \pm 0.0$ & $12.3^{\mathrm{b}} \pm 0.3$ \\
Fruit stalk & $253.3^{\mathrm{a}} \pm 5.8$ & $30.0 \pm 0.0$ & $125.0 \pm 0.0$ & $15.3^{\mathrm{c}} \pm 0.3$ & $110.0^{\mathrm{a}} \pm 0.0$ & $12.1^{\mathrm{b}} \pm 0.1$ \\
Leaf & $280.0^{\mathrm{b}} \pm 23.2$ & $35.0 \pm 3.7$ & $150.0 \pm 0.0$ & $12.3^{\mathrm{a}} \pm 0.3$ & $180.0^{\mathrm{d}} \pm 0.0$ & $10.5^{\mathrm{a}} \pm 0.0$ \\
\hline
\end{tabular}

All data were mean \pm standard deviation of triplicate determinations

Means within the same column with the same subscripts were not significantly different (Duncan's test)

content of the peel was highest and that of leaf lowest $(p<0.05)$.

The mineral composition of plantain wastes are shown in Table 2. There were significant differences in values of all the minerals for all the samples. Ripe peel was highest in sodium, bract was highest in potassium, magnesium and iron, while the leaf sample was highest in calcium and phosphorus $(p<0.05)$.

\section{DISCUSSION}

The moisture level (Table1) of the samples was very high compared to the value reported in the literature $(5.43 \%$, USDA, 2009). The moisture content of foods or its processed products gives an indication of its freshness and shelf life, and high moisture content subjects food items to increased microbial spoilage and short shelf life, which can lead to its deterioration (Adepoju and Onasanya, 2008). The leaf and the bract samples were relatively high in crude protein when compared with other sources of plant protein. They are higher than that of Shea butter fruit pulp (Adepoju and Ketiku, 2003), amaranthus and cocoyam leaves (Adepoju et al., 2006). Protein content of plantain ripe peel and fruit stalk powder was low compared with that of other widely eaten staple roots, tubers and fruits (Aurand, 1987; USDA, 2009), significantly lower than that of leaf and bract samples $(p<0.05)$, but higher than that of fluted pumpkin pod and pulp (Essien et al., 1992). Protein is an essential component of diet needed for survival of animals and human being, their basic function in nutrition is to supply adequate amount of required amino acids.
The crude fat content of samples of the plantain wastes was very low and may not be good source of fatsoluble vitamins nor can contribute significantly to energy content of the feeds that can be prepared with the wastes. Plantain fruit stalk and bract had the lowest and highest fat content respectively. Their low fat content will increase the storage life of the flour by reducing the chances of developing rancidity. The ash content of the samples was comparatively higher than those reported by previous researchers for agricultural hull (Adebowale and Bayer, 2002) and plantain peels (Adeyi and Oladayo, 2010). The high values of the ash were indicative of high mineral (especially the macrominerals) content of the wastes. Plantain leaf and fruit stalk recorded the lowest and highest value of ash respectively.

The plantain wastes were high in crude fibre, comparably higher than the value obtained for plant products such as Ube (Dacryodes edulis) $(2.1 \mathrm{~g} / 100 \mathrm{~g}$, Adepoju and Adeniji, 2008) and fruit pulp, (4.3g/100g, Adepoju and Adeniji, 2012). The increment may be attributed to the high total dietary fibre content found in the plantain waste especially peel (Haslinda et al., 2009). The plantain fruit stalk had the highest value of crude fibre, closely followed by ripe peel, with the leaf having the lowest value. High fibre content in diets have been reported to result in increased removal of potential mutagens, steroids and xenobotics by binding or absorbing to dietary fibre components and thereby aids digestion; hence these wastes will have health promoting benefits for livestock and fish farming. The samples were high in carbohydrate content and can be good sources of energy for the animals. The peel had highest value of carbohydrate while the leaf had the lowest value. 
The mineral content of the samples were high in sodium, calcium, phosphorus and potassium, but low in iron and magnesium (Table 2). Bract was highest in potassium, magnesium and iron content, the peel highest in sodium while the leaf was highest in calcium and phosphorus content. The wastes can be good sources of calcium, phosphorus and iron. Calcium and phosphorus are very important in the formation of strong bones and teeth, for growth, blood clotting, heart function and cell metabolism (Roth and Townsend, 2003; Rolfe et al., 2009). Potassium is an important raw material in soap production and in soil neutralization (Adeolu and Enesi, 2013). The iron level of the wastes was higher than the values recorded for dry guinea corn leaf extracts $(1.2 \mathrm{mg}$ $2.1 \mathrm{mg} / 100 \mathrm{~g}$, Adepoju, 2007) and fresh and roasted Dacryodes edulis fruit $(7.0 \mathrm{mg}$ and $3.0 \mathrm{mg} / 100 \mathrm{mg}$ respectively, Adepoju and Adeniji, 2008). Being rich in macrominerals, it can also be formulated into instant flours for convalescence and in the formulation of baby foods as these categories of humans require high levels of minerals for growth and repair.

\section{CONCLUSION}

The plantain wastes were rich in crude fibre, carbohydrates and ash and can serve as basal materials or components of animal feed. The leaf and bract samples were high in crude protein, and can serve as protein source for animal feed if bioavailable. The wastes were high in calcium, phosphorus, and iron, and can be good source of these minerals. Plantain wastes pose to be potential good sources of nutrients for production of animal feeds, and their utilisation for this purpose should be encouraged, as this will also help in reducing the menace of plantain waste in the environment.

\section{REFERENCES}

Adebowale KO, Bayer $\mathrm{E}(2002)$. Active carbons from low temperature conversion chars. Electronic J. Environ. Agric. Food Chem. 7(11), 3304-3315.

Adeniji TA, Sanni LO, Barimalaa IS, Hart AD (2006). Determination of micronutrients and colour variability among new plantain and banana hybrids flours. World J. Chem. 1(1): 23-27.

Adeolu AT, Enesi DO(2013). Assessment of proximate, mineral, vitamin and phytochemical compositions of plantain (Musa paradisiaca) bract - an agricultural waste. Int. Res. J. of Plant Science 4(7), 192197.

Adepoju OT, Adeniji $\mathrm{PO}(2008)$. Nutrient composition, anti-nutritional factors and contribution of native pear (Dacryoides edulis) pulp to nutrient intake of consumers. Nig J Nutr Sci 29(2), $15-23$.

Adepoju OT, Onasanya LO(2008). Nutrient composition and antinutritional factors of

Adepoju OT, Onasanya LO, Udoh C H(2006). Comparative studies of nutrient composition

Adepoju OT (2007). Nutrient composition, anti-nutritional factors and contribution of dry guinea

Adeyi , Oladayo (2010). Proximate composition of some agricultural wastes in Nigeria and their potential use in activated carbon production. J. Appl. Sci Environ. Manage. 14(1), 55-58.
Ahenkora K, Kyei MA, Marfo EK, Banful B (1996). Nutritional composition of False Horn Apantu plantain during ripening and processing. Afr. Crop Sci. J. 4(2): 243-247.

AOAC (1990). Official Methods of Analysis of the Association of Official Analytical Chemists, 15th ed., AOAC, Arlington, Virginia, USA.

AOAC, (1995). Official methods of analysis (15 ${ }^{\text {th }}$ edn) Association of Official Analytical Chemists. Arlington, V. A. USA.

Aurand WL (1987). Food composition and analysis of food, Von Nostrand Reinhold, New York, pp.135-138.

Bingham SA(1990). Mechanisms and experimental and epidemiological evidence relating dietary fibre (non-starch polysaccharides) and starch to protection against large bowel cancer. Proc. Nutr. Soc. 49, 153-171.

Bingham SA(1992). Plant cell wall material and cancer prevention: Chemical and Biological aspects (special publication No. 123); eds Waldron K W, Johnson I T \& Fenwick G. R. The Royal Soc Chem Lond. U. K. Pp 339-347.

Bonire JJ, Jalil NSN, Lori JA(1990) Sodium and potassium content of two cultivars of white yam (Dioscorea rotundata) and their source soils. J Sci Food Agric. 53. 271-274.

Burton TB, Willis RF (1976). Human nutrition, 4th edition, McGraw Hill Book Company, New York, pp. 566-588.

corn leaf extract to nutrient intake of consumers. Nig J Nutr Sci 28(1), $140-148$.

Danso KE, Adomako D, Dampare SB, Oduro V(2006). Nutrient status of edible

Dialium guineense Wild fruit pulp Ife J Sci 10 (1), $33-37$.

Dzomeku BM, Armo-Annor F, Adjei-Gyan K, Darkey SK (2007). Consumer preference for three selected Musa hybrids in Ghana. Am. J. Food Technol. 2(7): 684-688.

Edn Wadsworth Cengage Learning. Pp B, 383.

Essien Al, Ebana RUB, Udo HB(1992). Chemical evaluation of pod and pulp of the fluted pumpkin (Telfaira occidentalis) fruit. Food Chem. 45, 175-178.

Gill, LS: Ethnomedicinal uses of plants in Nigeria. University of Benin Press, Benin City, Nigeria,. pp. 169-170, 1992.

Grifiths DW (1981). The phenolic content and enzyme inhibitory activity of testa from beans (Vicia faba) and pea (Pisum spp) varieties. $J$ Sci Food Agric 32: 797-804.

Haslinda WH, Cheng LH, Chong LC, Noor Aziah AA (2009). Chemical composition and physicochemical properties of green banana flour. Int. J. Of Food sciences and Nutrition, 60(S4): 232-239.

International Institute for Tropical Agriculture, Ibadan, Nigeria, Amarin Printing Group Co. Ltd., Thailand. p. 24.

Izonfuo W-AL, Omuaru VOT (1988). Effect of ripening on the chemical composition of plantain peels and pulps (Musa paradisiaca). J. Sci. Food Agric. 45: 333-336.

Jagirdar SAP, Ansari AR(1966). Proc Agric. Symp 71.

Ketiku AO(1973). Chemical composition of unripe and ripe plantain (Musa paradisiaca). J. Sci food Agric 24, 703-707.

Martin-Tanguy J, Guillaume J, Kossa A (1977) Condensed tannins in horse bean seeds: chemical structure and apparent effect on poultry. J Sci Food Agric 28 757-765.

McLeod MN (1974) Plant tannins-their role in forage quality. Nutr Abst Rev 44 803-815.

Moseley G, Grifiths D W (1979) Varietal variation in the antinutritive effects of field beans (Vicia faba) when fed to rats. J Sci Food Agric $30772-778$.

$\mathrm{Ng} \mathrm{SP}$, Fong CS (2000). Banana enhances your anti-cancer power. In: Health discovery. Petaling Jaya Malalysia: Life Publisher Berhad.

of cocoyam (Colocassia esculenta) leaf with some green leafy vegetables. Nig J. Nutr Sci. 27 (1), $22-26$.

Oladiji AT, Idoko AS, Abodunrin TP, Yakubu MT(2010).Studies on the physicochemical properties and fatty acid composition of the oil from ripe plantain peel(Musa paradisiaca). African Scientist, 11(1) 73-78.

Ologhobo AD, Fetuga BL(1983). Investigation on the trypsin inhibitor, hemagglutinin, phytic and tannic acid contents of cowpea Vigna Unguiculata. Food Chem .; 12 (4), 249-254.

Omole AJ, Ajasin FO, Oluokun JA, Obi, OO(2008) Performance characteristics of weaned rabbit fed plantain peel as replacement for maize. J. Nutr. Food. 38:559-563. 
Osma JF, Herrera JLT, Couto Sr (2007). Banana skin: A novel waste for lactase production by Tramets pubescens under solid-state conditions. Application to synthetic dye decolouration. Dye pigments $\& 5: 32-37$.

Philips TA (1982). An Agricultural Notebook. Longman, Nigeria p.125.

plantains (Musa spp) as determined by instrumental neutron activation analysis. Journal of Radioanalytical and Nuclear Chemistry, 270(2): 407-411.

Rolfes SR, Pinna K, Whitney E(2009). Understanding normal and clinical nutrition. Eighth

Roth AR, Townsend CE(2003). Nutrition and diet therapy $8^{\text {th }}$ edn. Delmar Learning, Thomson Learning Inc. Canada. Pp 132 and cover page.

Saura-Calixto F, Canellas J, Soler L(1983). Dietary fibre components of the nitrogen free extract of almond kernels. J. Sci. Food Agric 36, 1419-1422.

Stover RH, NW Simmonds(1987). Bananas. Tropical agricultural series, third edition. John Wiley and Sons, Inc., N.Y. 10158: p. 468.

Swennen R(1990a). Limits of mophotaxonomy of plantain in Africa and elsewhere. Genet. Res. Crop Evol. 18: 172-210.
Swennen R(1990b). Plantain cultivation under West African conditions: A reference manual.

USDA (2005). Plantains. National Nutrient Database for Standard Reference, Release 18.

http://www.everynutrient.com/files/Health_Benefits_of_Plantains.mht Accessed on 6/2/2012.

USDA (2009). National Nutrient Database for Standard Reference, Release 22. http://www.nal.usda.gov/fnic/foodcomp/plantain/.

Welford A, Izonfuo L, Victor F (1988). Effect of ripening on the chemical composition of plantain peels and pulps (Musa paradisiaca). J. Sci. Food Agric. 45: 333-336.

Wilson GF (1987). Status of banana and plantain breeding strategies. In: Persley GJ and De Langhe E (eds.). Proceeding of an international workshop held at Cairns, Australia, 13-17 Oct. 1986.

Xiao R, Beck O, Hjemdahn P (1998). The accurate measurement of serotoxin in white blood. Scandavia J. Clin. Lab. Invest. 58(6): 2326. 